\title{
Rapid Holocene climate changes in the North Atlantic: evidence from lake sediments from the Faroe Islands
}

\author{
CAMILLA S. ANDRESEN, SVANTE BJÖRCK, MATS RUNDGREN, DANIEL J. CONLEY AND CATHERINE JESSEN
}

\section{BOREAS}

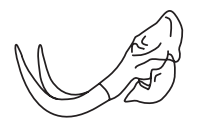

\begin{abstract}
Andresen, C. S., Björck, S., Rundgren, M., Conley, D. J. \& Jessen, C. 2006 (February): Rapid Holocene climate changes in the North Atlantic: evidence from lake sediments from the Faroe Islands. Boreas, Vol. 35, pp. 23-34. Oslo. ISSN 0300-9483.

Holocene records from two lakes on the Faroe Islands were investigated to determine regional climatic variability: the fairly wind-exposed Lake Starvatn on Streymoy and the more sheltered Lake Lykkjuvötn on Sandoy. Sediment cores were analysed for content of biogenic silica, organic carbon and clastic material, and magnetic susceptibility. In addition, a new qualitative proxy for past lake ice cover and wind activity was developed using the flux of clastic grains that are larger than $255 \mu \mathrm{m}$. Both long-term and short-term climatic developments were similar between the two lakes, suggesting a response to a regional climate signal. The long-term climate development is characterized by early Holocene rapid warming followed by Holocene climatic optimum conditions ending around 8300 cal. yr BP. A more open landscape as evidenced from increased sand grain influx in the period 8300-7200 cal. yr BP could reflect the aftermath of the 8200 cal. yr BP event, although the event itself is not recognized in either of the two lake records. From around $7200 \mathrm{cal}$. yr BP the mid-Holocene climate deterioration is observed and from $4200 \mathrm{cal}$. yr BP the climate deteriorated further with increased amplitude of centennial cooling episodes.
\end{abstract}

Camilla S. Andresen (e-mail: camilla.andresen@geol.lu.se), Svante Björck, Mats Rundgren and Catherine Jessen, GeoBiosphere Science Centre, Quaternary Sciences, University of Lund, Sölvegatan 12, SE-22362 Lund, Sweden; Daniel J. Conley, National Environmental Research Institute, Department of Marine Ecology, Frederiksborgvej 399, DK-4000 Roskilde, Denmark and Department of Marine Ecology, University of Aarhus, Finlandsgade 14, DK-8200 Arhus, Denmark; received 10th May 2005, accepted 25th July 2005.
In recent years, the debate about the consequences of global warming has placed increased focus on the role of the Atlantic Ocean in various climatic scenarios. The Faroe Islands have a key position in this context because of their proximity to the boundary between sub-arctic and Atlantic water masses; this may allow even small regional climate fluctuations to be recorded in lake sediments. Despite this, however, the number of long continuous Holocene lacustrine records from the Faroe Islands is limited to the pollen analytical work of Jóhansen (1985). The interval 10000-11 000 cal. yr BP has been studied in detail on the basis of pollen analyses (Björck et al. 2001; Hannon et al. 2001, 2003), plant macrofossil analyses (Bennike et al. 1998) and fossil insect analyses (Buckland et al. 1998) of lacustrine sediments. The time interval after 2000 cal. yr BP has also been studied excessively on the basis of pollen and plant macrofossil analyses (Hannon et al. 2001; Hannon \& Bradshaw 2000) and fossil insect analyses (Buckland \& Dinnin 1998; Buckland et al. 1998) from lake and peat deposits, leaving a large and less studied gap (10000-2000 cal. yr BP) in the Holocene record.

As numerous palaeostudies from the North Atlantic region provide evidence that the Holocene has been a climatically relatively unstable period (Meese et al. 1994; Bond et al. 1997, 2001; Bianchi \& McCave, 1999; Stötter et al. 1999; Andrews \& Giraudeau
2003), our aim has been to investigate long-term and short-term climate signals on the basis of sediment from two lacustrine records representing the time interval approximately 10000 to 2000 cal. yr BP. The sediment was analysed for content of biogenic silica, organic carbon and clastic material, magnetic susceptibility and a new qualitative proxy for lake ice cover and wind activity.

\section{Study area}

The Faroe Islands are situated $675 \mathrm{~km}$ from the Norwegian coast within the main branch of the North Atlantic Current (Fig. 1) and consist of 18 islands of varying size. They reach altitudes of 600-800 $\mathrm{m}$ a.s.1. and are imprinted with glacial features such as cirque carved plateaus, U-shaped valleys and fjords, with no signs of Holocene re-glaciation (Humlum et al. 1996). The bedrock consists of Tertiary plateau basalts of homogeneous tholeithic composition with common phenocrysts of plagioclase (Rasmussen \& Noe-Nygaard 1970).

The climate is maritime, reflecting the strong influence from the warm North Atlantic Current, with cool summers and mild winters. Mean annual temperature at Torshavn is $6.5^{\circ} \mathrm{C}(1961-1990)$, with a mean maximum in August of $10.5^{\circ} \mathrm{C}$ and a mean minimum 


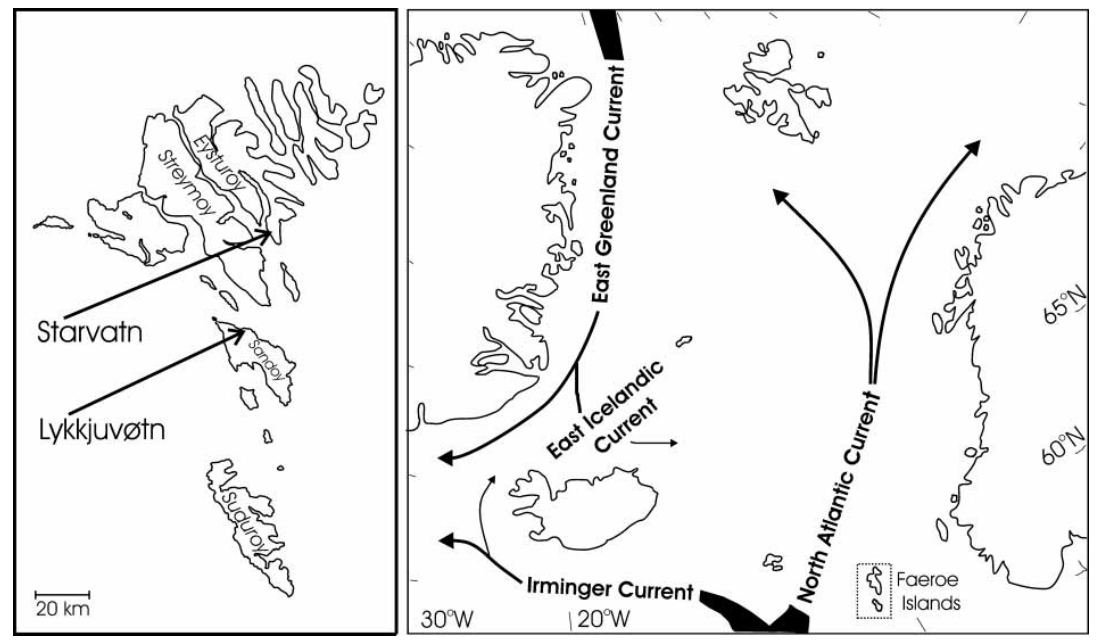

Fig. 1. Map of the North Atlantic Ocean and the Faroe Islands. Routes of major surface current systems are indicated.

in January of $3.2^{\circ} \mathrm{C}$. Annual precipitation increases from $850 \mathrm{~mm}$ in the west to $2750 \mathrm{~mm}$ in the mountainous northern and eastern parts and is highest during winter. Weather is usually very windy with prevailing winds from the southwest (Søgaard 1996) and frequent strong winds from the north during winter storms (Hansen 1990).

Sediment cores were studied from two geomorphologically different lakes situated $100 \mathrm{~km}$ apart (Fig. 1). Lake Starvatn (94 $\mathrm{m}$ a.s.1.) is situated on the island of Streymoy in a fairly exposed position on the Toftir peninsula and has previously been studied by Björck $e t$ al. (2001). It is $200 \times 50 \mathrm{~m}$ in size and water depth at the coring site is $0.4 \mathrm{~m}$. The lake has a small and indistinct inlet, and the outlet of the lake is regulated; it was possibly lowered and later dammed up again. The surrounding landscape is flat with frequent outcrops of bedrock. The other site, Lake Lykkjuvøtn (52 m a.s.1.), is situated on the northwestern corner of the island of Sandoy. It is $100 \times 25 \mathrm{~m}$ in extent and water depth at the coring site is $0.5 \mathrm{~m}$. The surrounding landscape is characterized by fairly steep slopes and occasional boulders, and is thus fairly sheltered from winds. The inlet of the lake is situated in the south and the outlet is connected to a second lake which has an outlet to the sea via a coastal cliff in the north. The distance to the nearest upwind major coastal cliff is $50-100 \mathrm{~m}$. Both lakes are surrounded by heath, which is a typical current vegetation for the Faroe Islands (Tukhanen 1987) as well as a minor area of farmland at the south end of Lykkjuvøtn.

\section{Methods}

Cores were sampled with 10 and $7.5 \mathrm{~cm}$ diameter Russian chamber corers. Seven overlapping cores from Starvatn provide a $386 \mathrm{~cm}$ sediment sequence. Sixteen cores from Lykkjuvøtn provide a $394 \mathrm{~cm}$ sediment sequence. The sediments were described and subsampled with $2 \mathrm{~cm}$ resolution.

\section{Radiocarbon-dating}

Samples from 11 levels in Starvatn and 12 levels in Lykkjuvøtn were dated in the AMS radiocarbon laboratories in Lund, Sweden, and Poznan, Poland (Table 1A, B). The depth interval represented by the samples varies between 1 and $3 \mathrm{~cm}$, and because no identifiable terrestrial plant macrofossils were found at the sampled levels, bulk sediment was dated. Dating of bulk sediment samples from soft-water lakes in the Faroe Islands has proved to yield reliable ages (Björck \& Wohlfarth 2001). This has been corroborated by parallel radiocarbon-dating of bulk sediment and terrestrial macrofossils (Salix herbaceae leaves) at two levels below the Saksunarvatn ash in Lykkjuvøtn yielding overlapping calibrated ages at $2 \sigma$ (Jessen et al. in prep.). Moreover, it is supported by geochemical identification of dominantly Kebister/Hekla-S tephra particles in two visible and densely spaced tephra horizons sampled in the Starvatn sequence (S. Wastegård, pers. comm. 2005). These occur immediately below (depth $1.80 \mathrm{~m}$, thickness $1-2 \mathrm{~mm}$ ) and above (depth $1.77 \mathrm{~m}$, thickness $\leq 4 \mathrm{~mm}$ ) the radiocarbon-dated sample Poz-4537, which is calibrated to $4150-3910$ cal. yr BP $(2 \sigma)$ (Table 1$)$. This age is consistent with previous estimates for the Kebister/Hekla$\mathrm{S}$ tephra based on varve counting in lake sediments and radiocarbon-dating of peat (Zillén et al. 2001). Calibration of radiocarbon ages to cal. yr BP (years before AD 1950) was done using the OxCal v3.10 calibration program (Bronk Ramsey 1995, 2001) and INTCAL04 calibration data (Reimer et al. 2004). 
Table 1. List of radiocarbon-dated samples from Starvatn and Lykkjuvøtn.

\begin{tabular}{|c|c|c|c|c|}
\hline Depth (m) & Dated material & ${ }^{14} \mathrm{C}$ age \pm 1 stdv & $\begin{array}{l}\text { Calibrated age } 2 \sigma \\
\text { (cal. yr BP) }\end{array}$ & Lab. no. \\
\hline \multicolumn{5}{|l|}{ Starvatn } \\
\hline 0.700 & Bulk & $2045 \pm 30$ & $2120-1920$ & Poz-4531 \\
\hline 1.020 & Bulk & $2525 \pm 35$ & $2750-2480$ & Poz-4533 \\
\hline 1.445 & Bulk & $3315 \pm 30$ & $3640-3460$ & Poz-4534 \\
\hline 1.785 & Bulk & $3695 \pm 35$ & $4150-3920$ & Poz-4535 \\
\hline 1.845 & Bulk & $3820 \pm 35$ & $4410-4090$ & Poz-4537 \\
\hline 2.220 & Bulk & $4535 \pm 35$ & $5320-5050$ & Poz-4538 \\
\hline 2.620 & Bulk & $5210 \pm 35$ & $6180-5900$ & Poz-4539 \\
\hline 3.020 & Bulk & $5800 \pm 40$ & $6720-6490$ & Poz-4540 \\
\hline 3.400 & Bulk & $6305 \pm 40$ & $7320-7160$ & Poz-4541 \\
\hline 3.800 & Bulk & $7740 \pm 40$ & $8600-8430$ & Poz-4543 \\
\hline 4.056 & Saksunarvatn tephra & & 10240 & \\
\hline 4.305 & Bulk & $9840 \pm 50$ & $11360-11180$ & Poz-4544 \\
\hline \multicolumn{5}{|l|}{ Lykkjuvøtn } \\
\hline 0.610 & Bulk & $2315 \pm 30$ & $2370-2180$ & Poz-4561 \\
\hline 0.760 & Bulk & $2755 \pm 40$ & $2950-2770$ & LuA5568 \\
\hline 1.060 & Bulk & $3240 \pm 35$ & $3560-3380$ & LuA5569 \\
\hline 1.270 & Bulk & $4300 \pm 40$ & $4980-4820$ & Poz-4632 \\
\hline 1.460 & Bulk & $5020 \pm 40$ & $5900-5650$ & LuA5570 \\
\hline 1.700 & Bulk & $5620 \pm 50$ & $6500-6300$ & LuA5571 \\
\hline 2.100 & Bulk & $6660 \pm 60$ & $7620-7430$ & LuA5572 \\
\hline 2.500 & Bulk & $7040 \pm 60$ & $7970-7720$ & LuA5573 \\
\hline 2.900 & Bulk & $7370 \pm 60$ & $8340-8030$ & LuA5567 \\
\hline 3.125 & Bulk & $7980 \pm 50$ & $9000-8640$ & LuA5751 \\
\hline 3.345 & Bulk & $8120 \pm 50$ & $9270-8980$ & LuA5752 \\
\hline 3.555 & Bulk & $8310 \pm 50$ & $9460-9130$ & LuA5753 \\
\hline 3.730 & Saksunarvatn tephra & & 10240 & \\
\hline
\end{tabular}

\section{Magnetic susceptibility}

Fresh sediment was subsampled into $2 \times 2 \times 2 \mathrm{~cm}$ plastic containers and volume-specific magnetic susceptibility was measured using a Geofyzika Brno KLY2 susceptibility bridge and recalculated to mass specific (dry weight) magnetic susceptibility $\left(10^{-6} \mathrm{~m}^{3} \mathrm{~kg}^{-1}\right)$. A reliable composite profile was established on the basis of the magnetic susceptibility of the overlapping sediment cores.

\section{Loss on ignition}

Loss on ignition was performed in order to estimate water and organic matter content. Samples were weighed, dried for $12 \mathrm{~h}$ at $105^{\circ} \mathrm{C}$, reweighed and combusted for $2 \mathrm{~h}$ at $550^{\circ} \mathrm{C}$. As shown by a few test samples combusted at $925^{\circ} \mathrm{C}$, sediments did not contain any carbonate, which is not surprising in this bedrock setting. Since organic carbon represents 12/30 of the weight of organic material $\left(\left(\mathrm{CH}_{2} \mathrm{O}\right)_{n}\right)$, the amount of carbon can be estimated by dividing the amount of organic material by 2.5 .

\section{Biogenic silica}

The concentration of biogenic silica was estimated following the procedure described by Conley \& Schelske (2001), which is a modification of the DeMaster method $(1979,1991)$. Sediment subsamples
(30 mg freeze-dried sediment) were leached with a mild solution $(1 \%)$ of sodium carbonate for a period of $5 \mathrm{~h}$ in an $85^{\circ} \mathrm{C}$ shaking bath. Aliquots are withdrawn at 3 , 4 and $5 \mathrm{~h}$ and analysed for dissolved silica. Biogenic silica is generally dissolved after $2 \mathrm{~h}$ and any further leaching during the digestion stems from aluminosilicates. The amount of biogenic silica is estimated from the intercept of the line through the time course aliquots. In sediments with high biogenic silica concentrations a linear increase in dissolved silica concentration with time is seldom found. The analytical error of a sample can be larger than increases in dissolved silica concentration from mineral dissolution (Conley 1998). In cases of high biogenic silica content, the mean of two extractions of aliquots after $3 \mathrm{~h}$ of dissolution was used instead of the intercept.

The dry weight percentage of clastic material (nonbiogenic minerals and rocks) was estimated by taking the difference between dry weight percentage biogenic silica and dry weight percentage organic material.

\section{Grain-size analysis - a new proxy for lake ice cover and wind activity}

The concentration of clastic grains larger than $255 \mu \mathrm{m}$ was estimated by wet sieving a measured volume of sediment (spanning between 2 and $25 \mathrm{~cm}^{3}$ ) and the grains were counted under a stereo microscope. Two grain types were identified and separated: basalt rock grains and single grains of plagioclase. Usually between 
50 and 300 clastic grains were found per sample, with a mean of 150 . The flux of all grains (grains $\mathrm{cm}^{-2} \mathrm{yr}^{-1}$ ) was calculated as concentration of basalt and plagioclase grains (grains $\mathrm{cm}^{-3}$ ) $\times$ sedimentation rate $\left(\mathrm{cm} \mathrm{yr}^{-1}\right)$.

The basic concept behind this new climate proxy is the following. Transport of clastic grains larger than $255 \mu \mathrm{m}$ to the centre of a flat-bottomed lake has to be mediated by lake ice. Particles can either freeze into the ice when ice freezes on the beach or in shallow nearshore sediments. When the lake ice breaks up it can be transported by wind and/or currents towards the outlet, dropping particles along its path as the ice melts. Another possible mechanism for transport of large mineral grains into a lake is through the saltation of wind-transported particles on the lake ice. In both cases, lake ice is necessary to transport the particles to the centre of the lake. Wind-transported grains larger than $100 \mu \mathrm{m}$ are transported by saltation or surface creep (Tsoar \& Pye 1987), and may in cases be adhered to blowing snow particles. A grain size of $>255 \mu \mathrm{m}$ was chosen in order to make absolutely sure that none of the grains counted had been transported by subsurface currents.

The two lakes were specifically chosen for this experiment: they should have approximately the same local climate, i.e. be situated at approximately the same altitude and close to the sea, and they should have an outlet situated on the distal side of the lake in relation to the dominating wind direction (west-southwest).

It should be noted that lakes situated close to sea level rarely freeze over on the Faroe Islands today, and when they do the ice is usually thin and quickly melts. However, occasionally the Faroe Islands may experience an increased influence of cold air masses, when the Polar Front moves south, or when a tongue of polar water approaches the Faroe Islands from the northwest, often as an East Icelandic branch of the East Greenland Current (Humlum \& Christiansen 1998) (Fig. 1). Obviously, these situations may occur when the North Atlantic Current is weakened, which

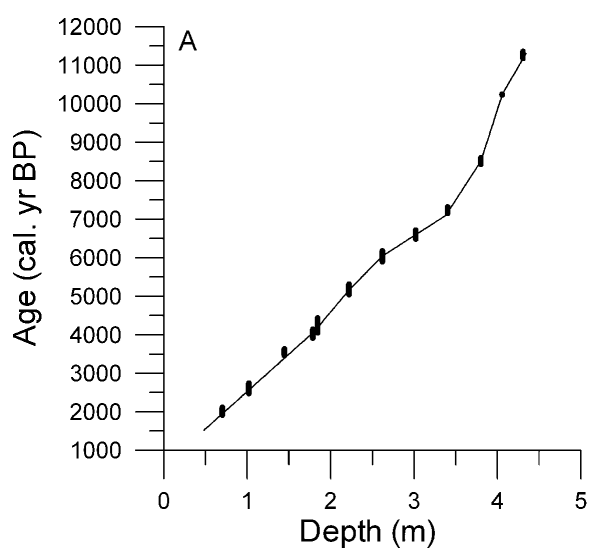

Fig. 2. Age models. A. Starvatn. B. Lykkjuvøtn. can cause prolonged periods of lake freezing, resulting in thicker ice with more clastic material.

\section{Principal component analysis}

In order to evaluate the interrelationship between the investigated proxies, a principal component analysis (PCA) was performed using Canoco 4.0 (ter Brak \& Smilauer 1998). The matrix was based on percentage data of biogenic silica, organic and clastic material and magnetic susceptibility, sedimentation rate and flux of grains $>255 \mu \mathrm{m}$ versus age. In order to obtain a comparable variability of the different proxies, the data-set values were standardized by log transformation.

\section{Data description}

\section{Starvatn}

The age model for Starvatn (Fig. 2A) is based on a number of linear segments adjusted to fit between the calibrated radiocarbon dates as well as a basaltic ash layer around $10200-10300$ cal. yr BP. This is the Saksurnavatn ash, dated to $10240 \mathrm{cal}$. yr BP in the GRIP ice-core record (Björck et al. 2001) and a well-known time marker in early Holocene lake sediments on the Faroe Islands (Jóhansen 1985; Edwards \& Craigie 1998; Wastegård et al. 2001). The sediment sequence (Fig. 3A) represents the time period from 11500 to 1500 cal. yr BP (Fig. 2A), with an overall increasing sedimentation rate throughout this interval from 0.03 to $0.05 \mathrm{~cm} \mathrm{yr}^{-1}$ (Fig. 3A). A maximum of $0.06 \mathrm{~cm} \mathrm{yr}^{-1}$ is observed between 7000 and $6000 \mathrm{cal}$. yr BP. The lack of sediments younger than $1500 \mathrm{cal}$. yr BP is most likely related to the infilling, shallowing and perhaps also anthropogenic lowering of the lake.

The sediments consist of clay gyttja during the earliest Holocene until $10700 \mathrm{cal}$. yr BP. This is followed by a fine detritus gyttja with a 0.5 -cm-thick Saksunarvatn tephra layer at $10240 \mathrm{cal}$. yr BP. From

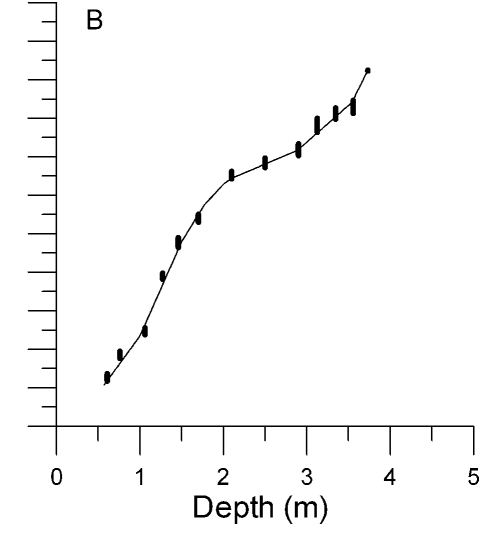




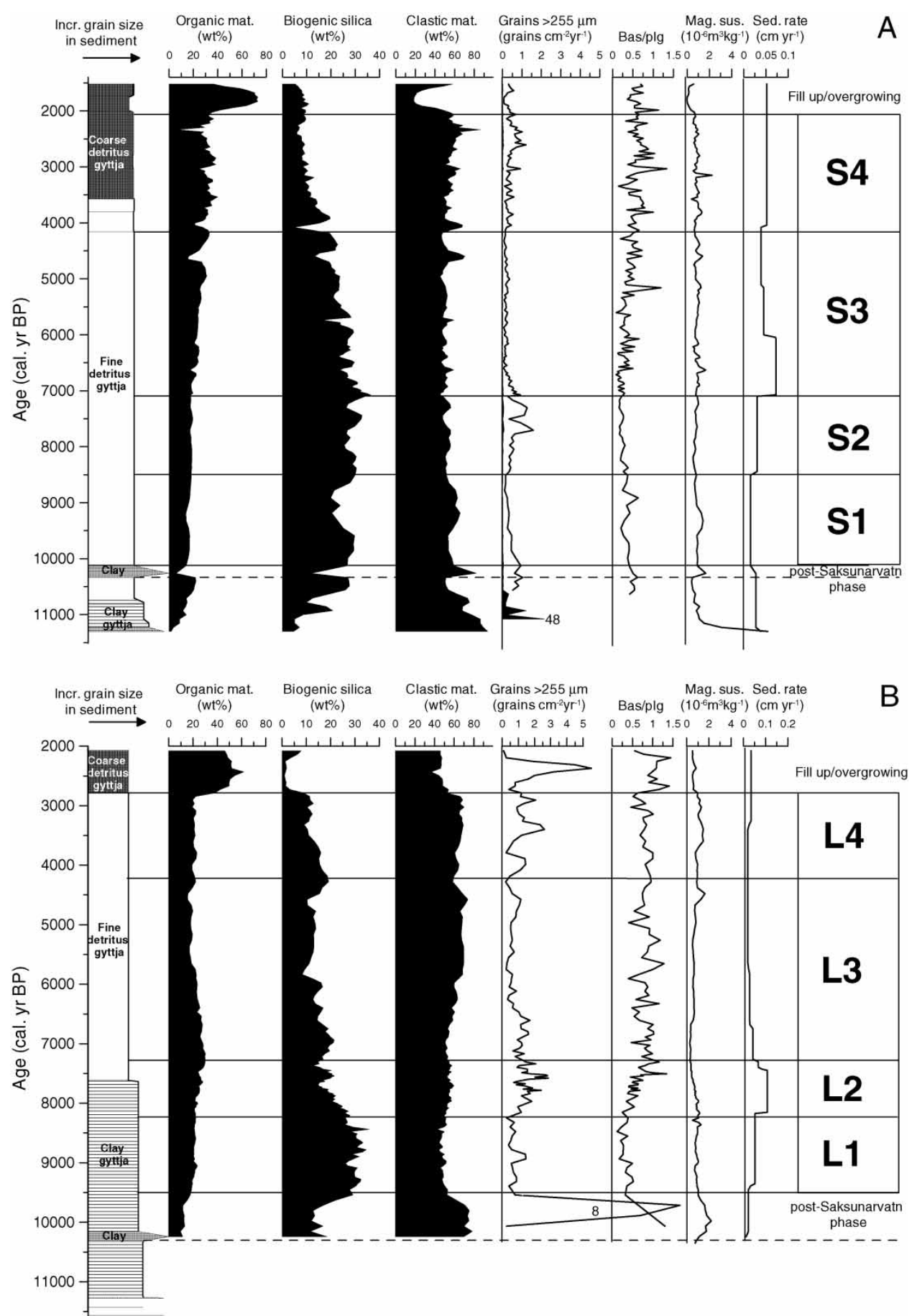

Fig. 3. Lithology, $w t \%$ of organic material, biogenic silica, clastic material, flux of grains $>255 \mu$ m, magnetic susceptibility and sedimentation rate. Zones defined on basis of PCA are indicated. A. Starvatn. B. Lykkjuvøtn.

3500 cal. yr BP until the top of the sequence, the sediment is a coarse detritus gyttja.

The amount of organic material increases slowly from around $20 \%$ during the earliest Holocene to $30 \%$ in the late Holocene. A marked and abrupt peak $(70 \%)$ is observed during the youngest 500 years of the sequence.
During the earliest Holocene, biogenic silica increases rapidly to values of $30 \%$, which last until 6000 cal. yr BP. After this period, values gradually decrease to $10 \%$ in the top. Short-term marked decreases of $5-15 \%$ are superimposed on this trend.

During the earliest millennium of the Holocene, the amount of clastic material decreases to a fairly 
constant value of $60 \%$, and this lasts throughout the sequence. At the top of the sequence, values decrease markedly to $20 \%$. Short-scale further increases of 10 $20 \%$ are superimposed on this trend.

The flux of sand grains larger than $255 \mu \mathrm{m}$ is very high during the early Holocene, with values up to 30 grains $\mathrm{cm}^{-2} \mathrm{yr}^{-1}$. After deposition of the Saksunarvatn tephra at $10240 \mathrm{cal}$. yr BP, values decrease markedly to between 0.5 and 1.0 grains $\mathrm{cm}^{-2} \mathrm{yr}^{-1}$. Two marked peaks are observed between 7500 and 6500 cal. yr BP (up to 1.6 grains $\mathrm{cm}^{-2} \mathrm{yr}^{-1}$ ) and increased values are observed between 4000 and $2000 \mathrm{cal}$. yr BP. High frequency fluctuations are further observed on these millennial scale fluctuations increasing in amplitude during the late Holocene.

The ratio between basalt and plagioclase grains (Bas/ plg) is generally relatively low (0.5), with a slightly decreasing tendency throughout the interval 10300 to 7000 cal. yr BP. Thereafter the values increase with a variable ratio (up to 1.3).

Magnetic susceptibility values are fairly constant throughout the entire Holocene, with values around $10^{-6} \mathrm{~m}^{3} \mathrm{~kg}^{-1}$ with some short-scale fluctuations. At the top of the sequence, the values decrease markedly.

\section{Lykkjuvøtn}

The age model for Lykkjuvøtn (Fig. 2B) is based on a number of linear segments adjusted to a best fit between the calibrated radiocarbon dates and the Saksunarvatn ash. The sediment sequence (Fig. 3B) represents the period 10300-2000 cal. yr BP. High resolution data representing 11500-10200 are in preparation (Jessen et al.) and will not be discussed here.

The period after deposition of the Saksunarvatn ash and until 9500 cal. yr BP is characterized by a relatively low sedimentation rate $\left(0.02 \mathrm{~cm} \mathrm{yr}^{-1}\right)$. Thereafter, values increase and a maximum of $0.1 \mathrm{~cm} \mathrm{yr}^{-1}$ can be observed between 8200 and 7500 cal. yr BP. After this period, sedimentation rates are low $\left(0.02 \mathrm{~cm} \mathrm{yr}^{-1}\right)$ with a minor increase around 3300 cal. yr BP to $0.03 \mathrm{~cm} \mathrm{yr}^{-1}$. The surface sediments are dated to $2000 \mathrm{cal}$. yr BP and it appears that no subsequent sedimentation occurred thereafter in this shallow lake.

Sediments consist of clay gyttja from the earliest Holocene until 7600 cal. yr BP, with the 0.5 -cm-thick Saksurnavatn ash at $10240 \mathrm{cal}$. yr BP. From 7600 to 2800 cal. yr BP the sediment comprised fine detritus gyttja followed by coarse detritus gyttja until the top of the sequence.

Concentrations of organic material vary around $15 \%$ in the period after deposition of the Saksunarvatn ash until 9500 cal. yr BP. This is followed by a slight increase to $20 \%$ with a wide small maximum in values of around 30\% between 8000 and 6000 cal. yr BP. A marked and abrupt peak $(50 \%)$ is observed during the youngest 1000 years of the sequence.
Values of biogenic silica are relatively low $(10 \%)$ for a period after deposition of the Saksunarvatn ash until 9500 cal. yr BP. At this time, values increase rapidly to a maximum of $30 \%$, lasting until 8000 cal. yr BP. Thereafter, the content of biogenic silica decreases to $10-15 \%$. A minimum is observed at the top of the sequence. Short-scale fluctuations of $5-10 \%$ are superimposed on the long-term changes.

The content of clastic material is relatively high $(75 \%)$ in the period after deposition of the Saksunarvatn ash until 9500 cal. yr BP. After this time, values decrease to $50 \%$ until around $6000 \mathrm{cal}$. yr BP, when an increase to $60 \%$ is observed lasting until 2500 cal. yr BP. At the top of the sequence, the values decrease to $50 \%$.

The flux of sand grains $>255 \mu \mathrm{m}$ is relatively high in the period after deposition of the Saksunarvatn ash until $9500 \mathrm{cal}$. yr BP, with values up to 8 grains $\mathrm{cm}^{-2} \mathrm{yr}^{-1}$. After 9500 cal. yr BP, values decrease to around 1 grain $\mathrm{cm}^{-2} \mathrm{yr}^{-1}$ interrupted by a broad maximum of $2-3$ grains $\mathrm{cm}^{-2} \mathrm{yr}^{-1}$ between 8000 and $6500 \mathrm{cal}$. yr BP. Around $4000 \mathrm{cal}$. yr BP, values increase again to $2-3$ grains $\mathrm{cm}^{-2} \mathrm{yr}^{-1}$. A marked peak of 6 grains $\mathrm{cm}^{-2} \mathrm{yr}^{-1}$ is observed at the top of the succession. In accordance with the Starvatn record, the long-term trend is superimposed by shortscale fluctuations with increasing amplitude during the late Holocene. However, it should be noted that, throughout the entire Holocene, the fluxes in general are around one order of magnitude higher in Lykkjuvøtn than in Starvatn.

The ratio between basalt and plagioclase grains decreases between 10300 and 9500 cal. yr BP from 1.5 to 0.5 . After this, the ratio is relatively low and constant but in the period 8200 to $7400 \mathrm{cal}$. yr BP values increase. In the remaining part of the Holocene the ratios are relatively high and variable with values up to 1.5 .

Magnetic susceptibility values are quite high (up to $2 \times 10^{-6} \mathrm{~m}^{3} \mathrm{~kg}^{-1}$ ) in the period after deposition of the Saksunarvatn ash until $9500 \mathrm{cal}$. yr BP. Thereafter the values decrease to $1-2 \times 10^{-6} \mathrm{~m}^{3} \mathrm{~kg}^{-1}$ with a minor broad minimum around 7000 and $6000 \mathrm{cal}$. yr BP. At the top of the sequence the values also display a minimum.

\section{Discussion}

As can be seen from Starvatn (Fig. 3A) the earliest Holocene (11 500-10240 cal. yr BP) is characterized by a climatic warming phase with rapidly increasing biogenic silica content and decreasing clastic content. The rapidly changing pattern of this interval is in accordance with earlier studies from the Faroe Islands (Björck et al. 2001; Hannon et al. 2003).

In both records, a time period influenced by redeposition of the Saksunarvatn ash has been recognized (post-Saksunarvatn phase in Fig. 3A, B). In Starvatn, 
this period lasted 50-100 years after the volcanic eruption at 10240 cal. yr BP, and is characterized by decreased values in biogenic silica and organic material and high values in the clastic-related components (clastic percentage, sand grain flux and magnetic susceptibility). In Lykkjuvøtn, this pattern continues for 600-700 years after ash deposition, but it is possible that this large difference may partly be related to inaccurate age models. We suspect that the postSaksunarvatn period is related to a change of landscape and sediment processes caused by the ash deposits unrelated to climatic change: primary tephra deposition in the lakes will, of course, manifest itself as raised clastic material percentages and lowered percentages of other major sediment components (organic material and biogenic silica). Following this primary phase, tephra deposited in the catchment will be transported with surface runoff, and to some extent also by wind, into the lakes. This will result in continued dilution of the sediments with mineral material, but part of the observed change in sediment composition after tephra fallout may reflect impact on the aquatic ecosystem (primarily algae, including diatoms; Lotter \& Birks 1993) by secondary tephra deposition. This process appears to have been more persistent in Lykkjuvøtn, which probably reflects the steeper slopes in the catchment and the better defined inflow to the lake. The peaks in the flux of grains $>255 \mu \mathrm{m}$ associated with the Saksunarvatn ash in the two sequences do not reflect increased input of coarse tephra particles, because no tephra particles of this size were encountered. Possibly, they represent increased production of mineral material in the catchment and exposure to wind related to a temporary decrease in the vegetation cover following tephra deposition.

A PCA was performed to evaluate climate processes and their impact on the development of the two lakes. It is clear that the top part of the sequence in both lakes is dominated by a high content of organic material related to the infilling of the lakes. This part of the record was removed prior to running the PCA, as we wanted to focus on long-term and short-term climate variability; a local event like lake infilling distorts the signal in the PCA. For the same reasons, the interval after deposition of the Saksunarvatn tephra (post-Saksunarvatn phase) was also removed prior to running the PCA. The interrelationship between the investigated proxies is illustrated by a biplot of 1 st and 2 nd axis score of the data set. The biplot obtained from both lake records shows a negative correlation between clastic material and biogenic silica, but also that the remaining proxies (sedimentation rate, organic material, magnetic susceptibility and flux of grains $>255 \mu \mathrm{m}$ ) are correlated to neither biogenic silica nor clastic material.

A number of zones were visually identified in the two reduced data sets, based on major changes in and 1st and 2nd axis scores (Fig. 4A, B). These zones correspond relatively well between the two lakes with regard to both timing and sediment characteristics. This zonation scheme was then transferred to the diagram showing proxies (Fig. 3A, B).

\section{Zone 1}

This zone lasts from 10100 to 8500 cal. yr BP in Starvatn and from 9500 to 8300 in Lykkjuvøtn, and is characterized by high biogenic silica content in both lakes (Figs 3A, B, 4A, B). The flux of grains to both lakes is relatively low. This probably reflects a mild climate with high lake production and reduced wind activity, and could be related to an early timing of the Holocene Optimum on the Faroe Islands, as they are located within the North Atlantic Current.

\section{Zone 2}

Zone 2 (8500-7100 cal. yr BP in Starvatn and 83007250 cal. yr BP in Lykkjuvøtn) is characterized by a slightly increased content of biogenic silica in Starvatn, whereas values decrease throughout this zone in Lykkjuvøtn. Sedimentation rate and influx of sand grains increase in both lakes, which could reflect an opening of the landscape, with soils being more exposed to wind. This concurs well with Jóhansen (1985), who, on the basis of pollen analyses, found an increase in the light-demanding plant Calluna between 7800 and $6800 \mathrm{cal}$. yr BP. There are no traces of the so-called 8.2 event (Dansgaard et al. 1993; Alley et al. 1997; Klitgaard-Kristensen et al. 1998; Barber et al. 1999; Johnsen 2001), but it could be argued that the overall opening of the landscape is related to the aftermath of a severe cooling episode. However, the lack of a marked cooling episode is also a common phenomenon in records from the Iceland-Greenland region (Andresen \& Björck 2005 and references therein).

\section{Zone 3}

This zone, lasting from 7100 to 4200 cal. yr BP in Starvatn and from 7250 to 4200 cal. yr BP in Lykkjuvøtn, is marked by a decrease in the influx of sand grains to both lakes. Biogenic silica starts decreasing in Starvatn, whereas biogenic silica values in Lykkjuvøtn continue their decreasing trend. In Starvatn, sedimentation rate increases markedly at the onset of this zone, whereas sedimentation in Lykkjuvøtn begins to decrease at the onset of the zone. This can be explained by the covariance between sedimentation rates and organic material in the lakes at this time.

Reduced lake productivity as interpreted from decreasing biogenic silica content is most likely related to an early onset of the mid-Holocene climate deterioration (frequently termed Neoglaciation in regions with glacier growth). This would also be in accordance with 


\section{A}
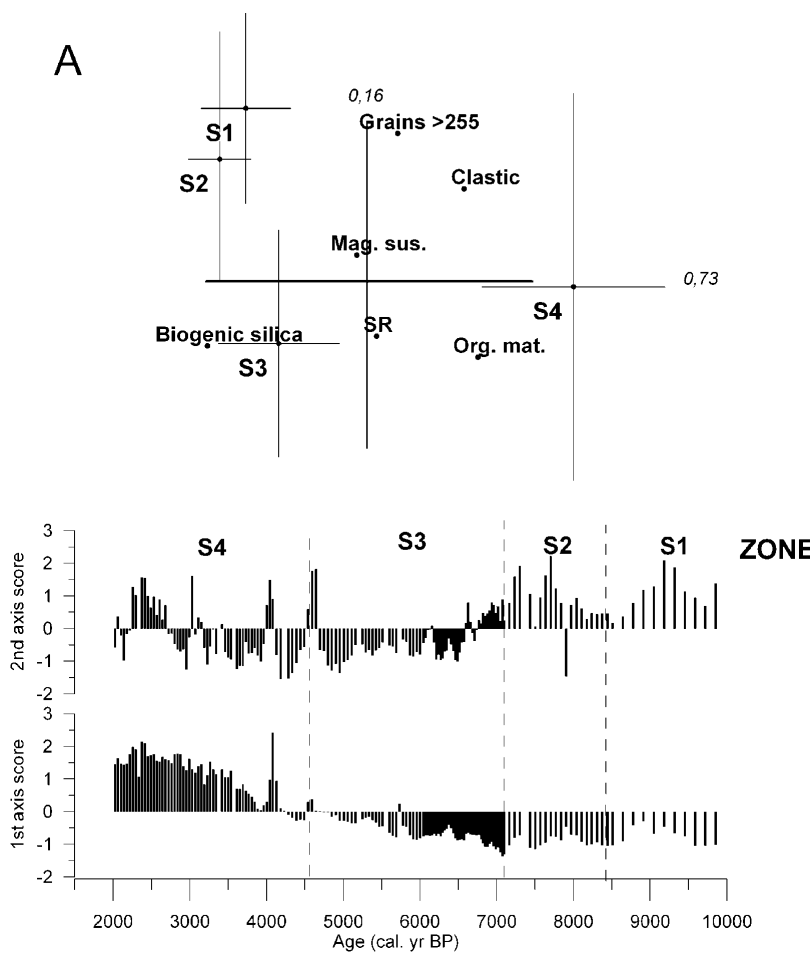

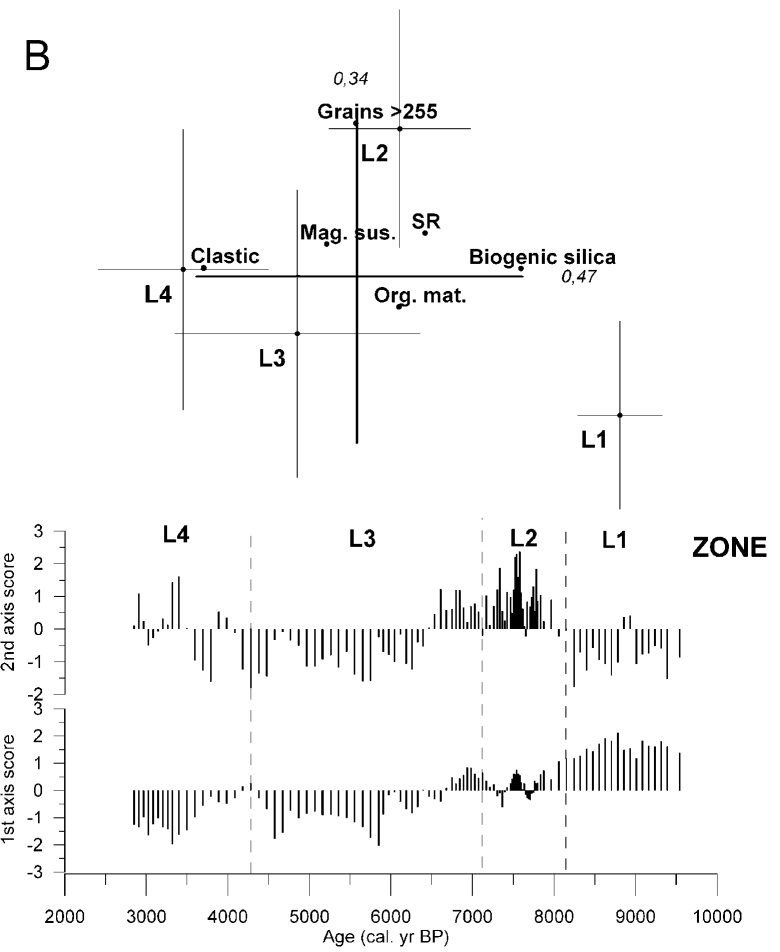

Fig. 4. Results from the principal component analysis. Biplot of 1st and 2nd axis of variables and bar chart plot of 1st and 2nd axis score. Eigen values are noted on biplot axes. A. Starvatn. B. Lykkjuvøtn.

the diatom-based winter sea surface temperature record from core MD952011 off the coast of central Norway (Birks \& Koç 2002; Andersen et al. 2004) (Fig. 6) documenting a long-term decrease in temperature starting around 7400 cal. yr BP.

The overall decrease in flux of sand grains is enigmatic because a harsher climate should favour more aeolian transport. However, at this time there was a shift in northern hemisphere insolation; summer insolation had decreased significantly, while winter insolation was increasing (Berger 1978). This would have resulted in shorter periods of lake ice. So, despite possible increased wind activity, the decreased extent of lake ice - being the prerequisite for sand grain deposition into the centre of the lakes - would result in an overall decreased flux of sand grains. Another possible cause would be a change in vegetation around the lakes, and thereby sediment availability. At this time soils had become more acidic and as a result the vegetation changed from grass and sedge-dominated plant communities with occasional Juniperus and Salix towards a more dense cover of heath and moisturedemanding plants (Jóhansen 1985), protecting soils from wind erosion.

In both lakes, the transition to this zone is characterized by an increase in the ratio and the variability of basalt/plagioclase. We believe that this is related to an overall change in the transport process: If grains are transported by wind across the landscape and lake ice surface, some selective abrasion of the more brittle basalt grains could be expected. In contrast, material originating from the lake shore and transported via ice would have been much less subjected to abrasion and therefore would contain more basalt relative to plagioclase. If periods of lake ice cover decreased and/or the amount of protective vegetation increased at the beginning of this zone the input of basalt-depleted windblown sand would decrease, explaining the observed increase in basalt/plagioclase ratio.

\section{Zone 4}

This zone begins at 4200 cal. yr BP in both lakes and ends at the time of the final infilling of the lakes at 2000 and 2800 cal. yr BP in Starvatn and Lykkjuvøtn, respectively. In both lakes, the content of biogenic silica decreases throughout the zone, whereas the flux of sand grains increases in amplitude. This probably reflects a strengthened setback in climate. In the south Greenland-Iceland region a setback in climate with increased amplitude of variability is also observed; however, it happens around 3500-3300 cal. yr BP (Funder \& Fredskild 1989; Koç et al. 1993; Andresen $\&$ Björck 2005). The asynchronous timing of this 'strengthened late Holocene setback' across wider regions may be related to different thresholds responses to changes in oceanography/climate across the North Atlantic Ocean and/or different routing of Atlantic 
waters in the Irminger and the North Atlantic Current, respectively.

\section{Centennial climate variability}

Although the lakes are more than $100 \mathrm{~km}$ apart and their topographic setting is fairly different, the biogenic silica content shows remarkably similar trends, even down to centennial time scales (Fig. 5). This suggests that biogenic silica can be used as a proxy for local aquatic productivity, but also for more regional scale environmental and climatic variability.

We have also tested the hypothesis that the flux of sand grains larger than $255 \mu \mathrm{m}$ can be used as a proxy for climate. Clearly, sediment availability (influenced by topography and vegetation), lake ice cover and wind activity influence the final deposition in the lake. Based on the local soil and topographic conditions, we believe that sediment availability probably explains the generally higher values in Lykkjuvøtn than in Starvatn. In contrast, it is assumed that short-scale variability is related mainly to the combined effects of increased lake ice cover and/or increased wind activity. As with biogenic silica content, the trend in the flux of sand grains is relatively similar between the two lakes (Fig. 5 ). The majority of minima in biogenic silica are accompanied by maxima in sand grain flux; this is particularly evident in both records after $4500 \mathrm{ca}-$ 1. yr BP (correlation coefficients between biogenic silica and sand grain flux are -0.44 and -0.45 for Starvatn and Lykkjuvøtn, respectively). This strengthens the hypothesis that sand grain flux can be used as a valid proxy for lake ice cover and/or wind activity. The hypothesis of significant influence on wind transport is verified by the good correspondence between sea salt spray (interpreted from sulphur content) and flux of grains larger than $255 \mu \mathrm{m}$ in the interval 11500 10200 cal. yr BP in Lykkjuvøtn (Jessen et al. in prep.).

The biogenic silica record is compared to the icerafted debris record from VEMA 29191 off the coast of Ireland (Bond et al. 2001) and the diatom-based winter sea surface temperature record from MD952011 (Birks \& Koç 2002; Andersen et al. 2004) (Fig. 6). It is clear that most of the short-lived cold periods that we have detected in the Faroe Island lakes coincide with increased ice-rafting in the waters off Ireland and that most events can be suggested to concur with decreased winter SST in the Norwegian Sea. However, the cold episodes in the Norwegian Sea are often slightly offset in the interval 8000 to 4000 cal. yr BP, which could be related to uncertain age models, which is particular true for marine ${ }^{14} \mathrm{C}$ models, and/or timing of climate variability. The latter suggestion is supported by Mayewski et al. (2004), who on the basis of an extensive worldwide study on Holocene climate variability, note that not all sites respond synchronously or equally during rapid climate changes (RCCs) despite their overall global extent.

It is possible that these cold episodes are related to incursion of arctic waters with sea ice and icebergs to more southerly areas. This would result in significantly decreased air temperatures over the Faroe Islands and the frequency/magnitude of northerly storms would increase. It has been suggested that submillennial-scale Holocene climate variability resembles events like the

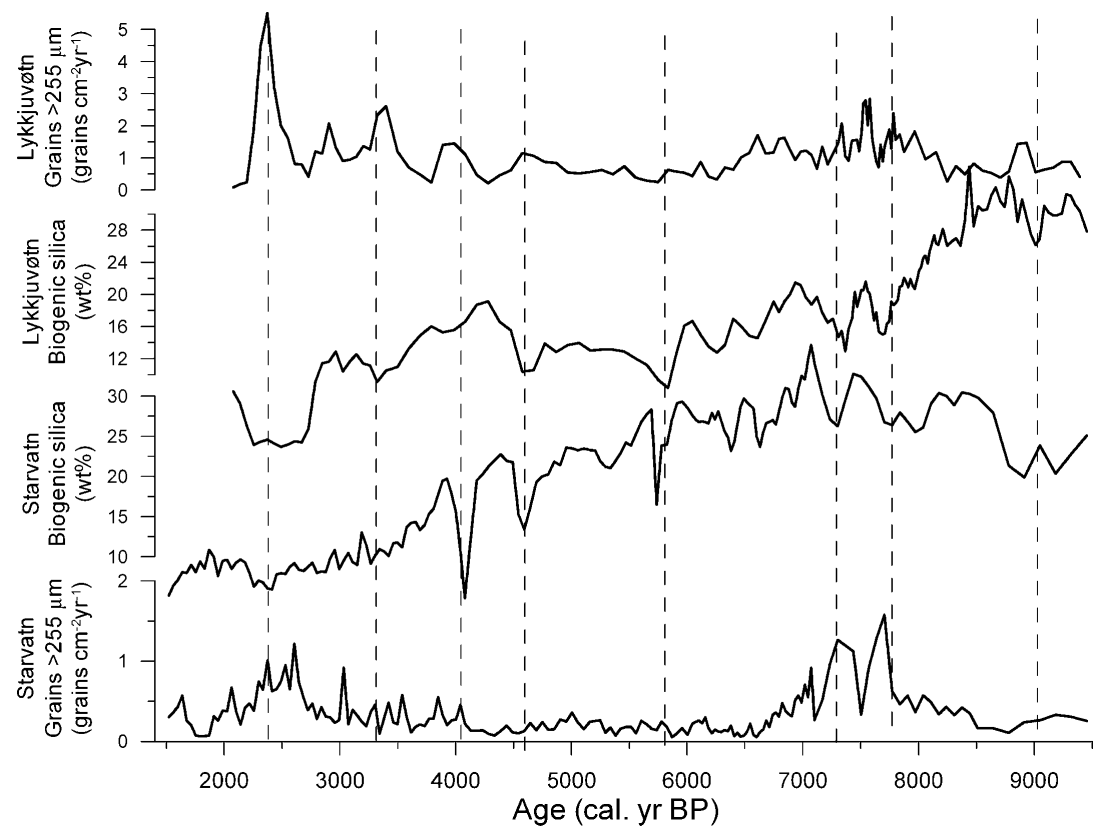

Fig. 5. Comparison between wt $\%$ biogenic silica and sand grain flux in Starvatn and Lykkjuvøtn. Stippled lines mark colder episodes. 


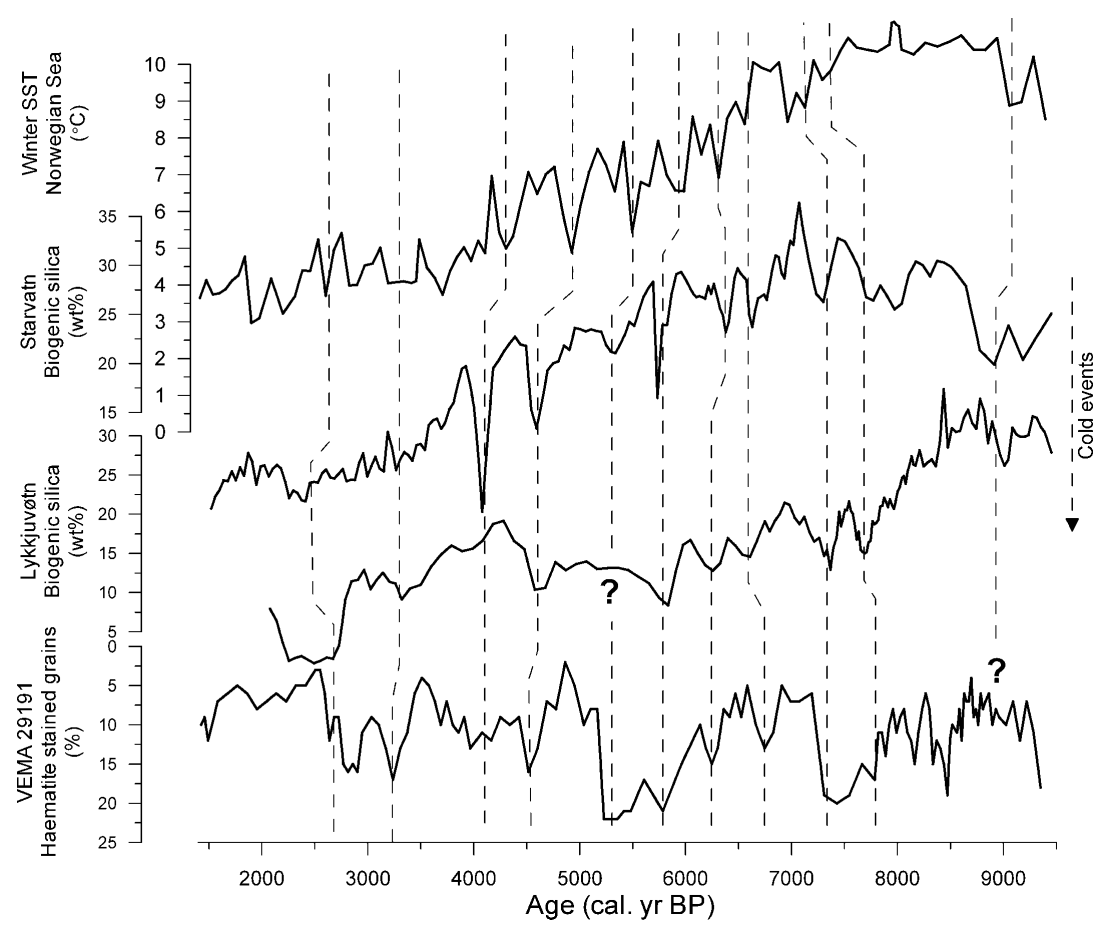

Fig. 6. Comparison between biogenic silica from the two Faroese lakes with the record of ice-rafted debris (haematite stained grains) from off west Ireland (VEMA 29191) (Bond et al. 2001) and the diatom-based winter sea surface temperature record from the Norwegian Sea (MD952011) (Birks \& Koc̣ 2002; Andersen et al. 2004).

Great Salinity Anomaly (GSA), but at a larger amplitude (Andrews et al. 2001a-c; Bond et al. 2001; Jennings et al. 2002; Andrews \& Giraudeau 2003; Andresen et al. 2004; Andresen \& Björck 2005). The GSA occurred as a large, near-surface pool of less saline water which circulated with the subpolar gyre during the late 1960s and 1970s as the result of an unusually large discharge of ice from the Arctic Ocean, and had a cooling influence on the ocean and atmosphere in the region it crossed (Dickson et al. 1975; Dickson \& Lamb 1976). Our results support such a scenario.

\section{Conclusions}

The long-term climate development on the Faroe Islands is characterized by early Holocene rapid warming followed by Holocene climatic optimum conditions ending around $8500-8300 \mathrm{cal}$. yr BP. The following 1000 years possibly reflect the aftermath of a cooling episode (the 8.2 event) and from 7200 cal. yr BP the mid-Holocene climate deterioration sets in with decreased productivity in the two lakes. A further setback in climate is observed around 4200 cal. yr BP, when lake ice occurrence and wind activity increase.

A new climate proxy, i.e. flux of grains larger than $255 \mu \mathrm{m}$, is presented and proposed to represent a qualitative measure of lake ice cover and wind activity.
The similarity in short-term variability in proxies of wind activity/lake ice cover and productivity in the two lakes suggests a response to a regional climate signal, most likely the inflow of polar waters to the eastern North Atlantic Ocean.

Acknowledgements. - Financial support to C. S. Andresen was kindly granted by Villum Kann Rasmussen Fonden and Carlsbergfondet. This study was supported by the Swedish Research Council (grant to M.R. and S.B.). We thank our reviewers Ole Humlum and Ole Bennike for constructive comments on the manuscript. Erika SuciuKrausz and Diana Serban are thanked for subsampling the sediment cores and carrying out the loss on ignition and magnetic susceptibility analyses.

\section{References}

Alley, R. B., Meese, D. A., Gow, A. J., Taylor, K. C., Cuffey, K. M., Grootes, P., Grootes, P. M., Zielinski, G. A., Ram, M., Spinelli, G. \& Elder, B. C. 1997: Visual-stratigraphic dating of the GISP2 ice core: basis, reproducibility, and application. Journal of Geophysical Research 102, 26367-26381.

Andersen, A., Koç, N., Jennings, A. \& Andrews, J. T. 2004: Nonuniform response of the major surface currents of the Nordic Seas to insolation forcing: implications for the Holocene climate variability. Paleoceanography 19, PA2003, doi: 10.1029/ 2002PA000873.

Andresen, C. S. \& Björck, S. 2005: Holocene climate variability in the Denmark Strait region - a land-sea correlation of new and existing climate proxy records. Geografiska Annaler A 87, 157-172.

Andresen, C. S., Björck, S., Bennike, O. \& Bond, G. C. 2004: Holocene climate changes in southern Greenland: evidence from lake sediments. Journal of Quaternary Science 19, 783-795. 
Andrews, J. T., Caseldine, C., Weiner, N. \& Hatton, J. 2001a: Late Holocene (ca. $4 \mathrm{ka}$ ) marine and terrestrial environmental change in Reykjarfjördur, north Iceland: climate and/or settlement? Journal of Quaternary Science 16, 133-143.

Andrews, J. T. \& Giraudeau, J. 2003: Multi-proxy records showing significant Holocene environmental variability: the inner N. Iceland shelf (Húnafloí). Quaternary Science Reviews 22, 175-193.

Andrews, J. T., Helgadóttir, G., Geirsdóttir, A. \& Jennings, A. E. 2001b: Multicentury-scale records of carbonate (hydrographic?) variability of the northern Icelandic margin over the last 5000 years. Quaternary Research 56, 199-206.

Andrews, J. T., Kristjánsdóttir, G. B., Geirsdóttir, A., Hardardóttir, J., Helgadóttir, G., Sveinbjörnsdóttir, Á. E., Jennings, A. E. \& Smith, L. M. 2001c: Late Holocene $(\sim 5$ cal ka) trends and century-scale variability of N. Iceland marine records: measures of surface hydrography, productivity, and land/ocean interactions. In Seivdov, D., Maslin, M. \& Haupt, B. (eds.): Oceans and Rapid Past and Future Climate Change: North-South Connections, 68-91. American Geophysical Union.

Barber, D. C., Dyke, A., Hillaire-Marcel, C., Jennings, A. E., Andrews, J. T., Kerwin, M. W., Bilodeau, G., McNeely, R. Southon, J., Morehead, M. D. \& Gagnon, J.-M. 1999: Forcing of the cold event of 8200 years ago by catastrophic drainage of Laurentide lakes. Nature 400, 344-348.

Bennike, O., Böcher, J., Konradi, P., Kuijpers, A. \& Larsen, B. 1998: Macrofossil studies of lacustrine sediments from Skálafjørdur, the Faroe Islands: preliminary results. Fródskaparrit 46, 267-275.

Berger, A. L. 1978: Long-term variations of daily insolation and Quaternary climatic changes. Journal of the Atmospheric Sciences $35,2362-2367$.

Bianchi, G. G. \& McCave, I. N. 1999: Holocene periodicity in North Atlantic climate and deep-ocean flow south of Iceland. Nature 397, 515-517.

Birks, C. J. A. \& Koç, N. 2002: A high-resolution diatom record of late-Quaternary sea-surface temperatures and oceanographic conditions from the eastern Norwegian Sea. Boreas 31, 323-344.

Björck, S., Muscheler, R., Kromer, B., Andresen, C. S., Heinemeier, J., Johnsen, S. J., Conley, D., Koç, N., Spurk, M. \& Veski, S. 2001: High-resolution analyses of an early Holocene climate event may imply decreased solar forcing as an important climate trigger. Geology 29, 1107-1110.

Björck, S. \& Wohlfarth, B. 2001: ${ }^{14} \mathrm{C}$ chronostratigraphic techniques in paleolimnology. In Last, W. M. \& Smol, J. P. (eds.): Tracking Environmental Change Using Lake Sediments. Volume 1. Basin Analysis, Coring, and Chronological Techniques, 205-245. Kluwer, Dordrecht.

Bond, G., Kromer, B., Beer, J., Muscheler, R., Evans, M. N., Showers, W., Hoffmann, S., Lotti-Bond, R., Hajdas, I. \& Bonani, G. 2001: Persistent solar influence on North Atlantic climate during the Holocene. Science 294, 2130-2136.

Bond, G., Showers, W., Cheseby, M., Lotti, R., Almasi, P., deMenocal, P., Priore, P., Cullen, H., Hajdas, I. \& Bonani, G. 1997: A pervasive millennial-scale cycle in North Atlantic holocene and glacial climates. Science 278, 1257-1266.

Bronk Ramsey, C. 1995: Radiocarbon calibration and analysis of stratigraphy: the OxCal program. Radiocarbon 37, 425-430.

Bronk Ramsey, C. 2001: Development of the radiocarbon program OxCal. Radiocarbon 43, 355-363.

Buckland, P. C. \& Dinnin, M. H. 1998: Insect faunas at Landnám: a palaeoentomological study at Tjørnuvík, Strymoy, Faroe Islands. Fródskaparrit 46, 277-286.

Buckland, P. C., Edwards, K. J. \& Sadler, J. P. 1998: Early Holocene investigations at Saksunardalur and the origins of the Faroese biota. Fródskaparrit 46, 259-266.

Buckland, P. C., Edwards, K. J., Sadler, J. P. \& Dinnin, M. H. 1998: Late Holocene insect faunas from Mykines, Faroe Islands, with observations on associated pollen and early settlement records. Fródskaparrit 46, 287-296.
Conley, D. 1998: An interlaboratory comparison for the measurement of silica in the marine environment. Marine Chemistry 63, $39-48$.

Conley, D. J. \& Schelske, C. L. 2001: Biogenic silica. In Smol, J. P., Birks, H. J. B. \& Last, W. M. (eds.): Tracking Environmental Change Using Lake Sediments: Biological Methods and Indicators, 284-293. Kluwer, Dordrecht.

Dansgaard, W., Johnsen, S. J., Clausen, H. B., Dahl-Jensen, D., Gundestrup, G., Hammer, U. C., Hvidberg, C. S., Sveinbjörnsdóttir, Á. E., Jouzel, J. \& Bond, G. 1993: Evidence for general instability of past climate from a 250-kyr ice-core record. Nature 364, 218-220.

DeMaster, D. J. 1979: The Marine Budgets of Silica and ${ }^{32}$ Si. Ph.D. dissertation, Yale University, $308 \mathrm{pp}$.

DeMaster, D. J. 1991: Measuring biogenic silica in marine sediments and suspended matter. In Hurd, D. C. \& Spenser, D. W. (eds.): Marine Particles: Analysis and Characterization. Geophysical Monograph 63, American Geophysical Union, 363-367.

Dickson, R. R. \& Lamb, H. H. 1976: A review of recent hydrometeorological event in the North Atlantic sector. ICNAF Special Publication 8, 35-62.

Dickson, R. R., Lamb, H. H., Malmberg, S. A. \& Colebrook, J. M. 1975: Climatic reversal in northern North Atlantic. Nature 256, $479-482$.

Edwards, K. J. \& Craigie, R. 1998: Palynological and vegetational changes associated with the deposition of Saksunarvatn ash in the Faroe Islands. Fróðskaparrit 46, 193-206.

Funder, S. \& Fredskild, B. 1989: Paleofaunas and Floras (Greenland). In Foulton, R. J. (ed.): Quaternary Geology of Canada and Greenland, 775-783. Geological Survey of Canada, Toronto.

Hannon, G. E. \& Bradshaw, R. H. W. 2000: Impacts and timing of the first human settlement on vegetation of the Faroe Islands. Quaternary Research 54, 404-413.

Hannon, G. E., Bradshaw, R. H. W. \& Wastegård, S. 2003: Rapid vegetation change during the early Holocene in the Faroe Islands detected in terrestrial and aquatic ecosystems. Journal of Quaternary Science 18, 615-619.

Hannon, G. E., Hermanns-Audardóttir, M. \& Wastegård, S. 1998: Human impact at Tjørnuvík in the Faroe Islands. Fródskaparrit 46, $215-228$

Hannon, G. E., Wastegård, S., Bradshaw, E. \& Bradshaw, R. H. W. 2001: Human impact and landscape degradation on the Faroe Islands. Biology and Environment: Proceedings of the Royal Irish Academy 101B, 129-139.

Hansen, L. E. 1990: Jordbundsudviklingen I Leynavatnområdet. M.Sc. thesis, University of Copenhagen, $112 \mathrm{pp}$.

Humlum, O., Christiansen, H. H., Svensson, H. \& Mortensen, L. E. 1996: Moraine systems in the Faroe Islands: glaciological and climatological implications. Danish Journal of Geography 96, $21-$ 31.

Humlum, O. \& Christiansen, H. H. 1998: Late Holocene climatic forcing and geomorphic activity in the Faroe Islands, North Atlantic Ocean. Fródskaparrit 46, 119-140.

Jennings, A. E., Knudsen, K. L., Hald, M., Hansen, C. V. \& Andrews, J. T. 2002: A mid-Holocene shift in Arctic sea-ice variability on the East Greenland Shelf. The Holocene 12, 49-58.

Jóhansen, J. 1985: Studies in the vegetational history of The Faroe and Shetland Islands. Annales Societatis Scientiarum Foroensis Supplementum XI, $117 \mathrm{pp}$.

Johnsen, S. J. 2001: Oxygen isotope and paleotemperature records from six Greenland ice-core stations: Camp Century, DYE-3, GRIP, GISP2, Renland and NorthGRIP. Journal of Quaternary Science 16, 299-307.

Klitgaard-Kristensen, D., Sejrup, H. P., Haflidason, H., Johnsen, S. J. \& Spurk, M. 1998: A regional 8200 cal. yr BP cooling event in NW Europe. Journal of Quaternary Science 13, 165-169.

Koç, N., Jansen, E. \& Haflidason, H. 1993: Paleoceanographic reconstructions of surface conditions in the Greenland, Iceland 
and Norwegian Seas through the last $14 \mathrm{ka}$ based on diatoms. Quaternary Science Reviews 12, 115-140.

Lotter, A. F. \& Birks, H. J. B. 1993: The impact of the Laacher See Tephra on terrestrial and aquatic ecosystems in the Black Forest, southern Germany. Journal of Quaternary Science 8, $163-176$.

Mayewski, P. A., Rohling, E. E., Stager, J. C., Karlén, W., Maasch, K. A., Meeker, L. D., Meyerson, E. A., Gasse, F., van Kreveld, S., Holmgren, K., Lee-Thorp, J., Rosqvist, G., Rack, F., Staubwasser, M., Schneider, R. R. \& Steig, E. J. 2004: Holocene climate variability. Quaternary Research 62, 243-255.

Meese, D. A., Gow, A. J., Grootes, P., Mayewski, P. A., Ram, M., Stuiver, M., Taylor, K. M., Waddington, K. C. \& Zielinski, G. A. 1994: The accumulation record from the GISP2 record as an indicator of climate change throughout the Holocene. Science 266, $1680-1682$.

Rasmussen, J. \& Noe-Nygaard, A. 1970: Geology of the Faeroe Islands. Danmarks Geologiske Undersogelse 1, 25 pp.

Reimer, P. J., Baillie, M. G. L., Bard, E., Bayliss, A., Beck, J. W., Bertrand, C. J. H., Blackwell, P. G., Buck, C. E., Burr, G. S., Cutler, K. B., Damon, P. E., Edwards, R. L., Fairbanks, R. G., Friedrich, M., Guilderson, T. P., Hogg, A. G., Hughen, K. A., Kromer, B., McCormac, G., Manning, S., Bronk Ramsey, C., Reimer, R. W., Remmele, S., Southon, J. R., Stuiver, M., Talamo, S., Taylor, F. W., van der Plicht, J. \& Weyhenmeyer, C. E. 2004: INTCAL04 terrestrial radiocarbon age calibration, $0-26 \mathrm{cal}$ kyr. Radiocarbon 46, 1029-1058.
Stötter, J., Wastl, M., Caseldine, C. \& Häberle, T. 1999: Holocene palaeoclimatic reconstruction in northern Iceland: approaches and results. Quaternary Science Reviews 18, 457-474.

Søgaard, H. 1996: Climate and weather. In Guttesen, R. (ed.): Atlas of Denmark Series II, Volume 5. The Faroe Islands Topographical Atlas, 24-7. C. A. Reitzels Forlag for Det Kongelige Danske Geografiske Selskab and Kort og Matrikelstyrelsen, Copenhagen. ter Brak, C. J. F. \& Smilauer, P. 1998: Canoco for Windows. Centre for Biometry, Wageningen.

Tsoar, H. \& Pye, K. 1987: Dust transport and the question of desert loess formation. Sedimentology 34, 139-153.

Tukhanen, S. 1987: The phytogeographical position of the Faeroe Islands and their ecoclimatic correspondences on the other continents: problems associated with highly oceanic areas. Annales Botanici Fennici 24, 111-135.

Wastegård, S., Björck, S., Grauert, M. \& Hannon, G. E. 2001: The Mjáuvøtn tephra and other Holocene tephra horizons from the Faroe Islands: a link between the Icelandic source region, the Nordic Seas, and the European continent. The Holocene 11, 101109.

Zillén, L., Wastegård, S. \& Snowball, I. F. 2001: Calendar year ages of three mid-Holocene tephra layers identified in varved lake sediments in west central Sweden. Quaternary Science Reviews 21, $1583-1591$. 